\section{E- LOGOS}

ELECTRONIC JOURNAL FOR PHILOSOPHY ISSN 1211-0442

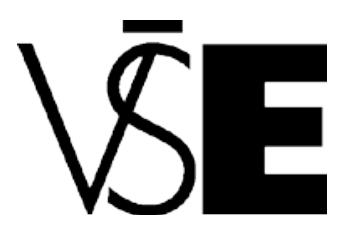

University of Economics

Prague

\title{
Humovy ideje filosofie jako vědy a tematizace času
}

Tomáš Kunca

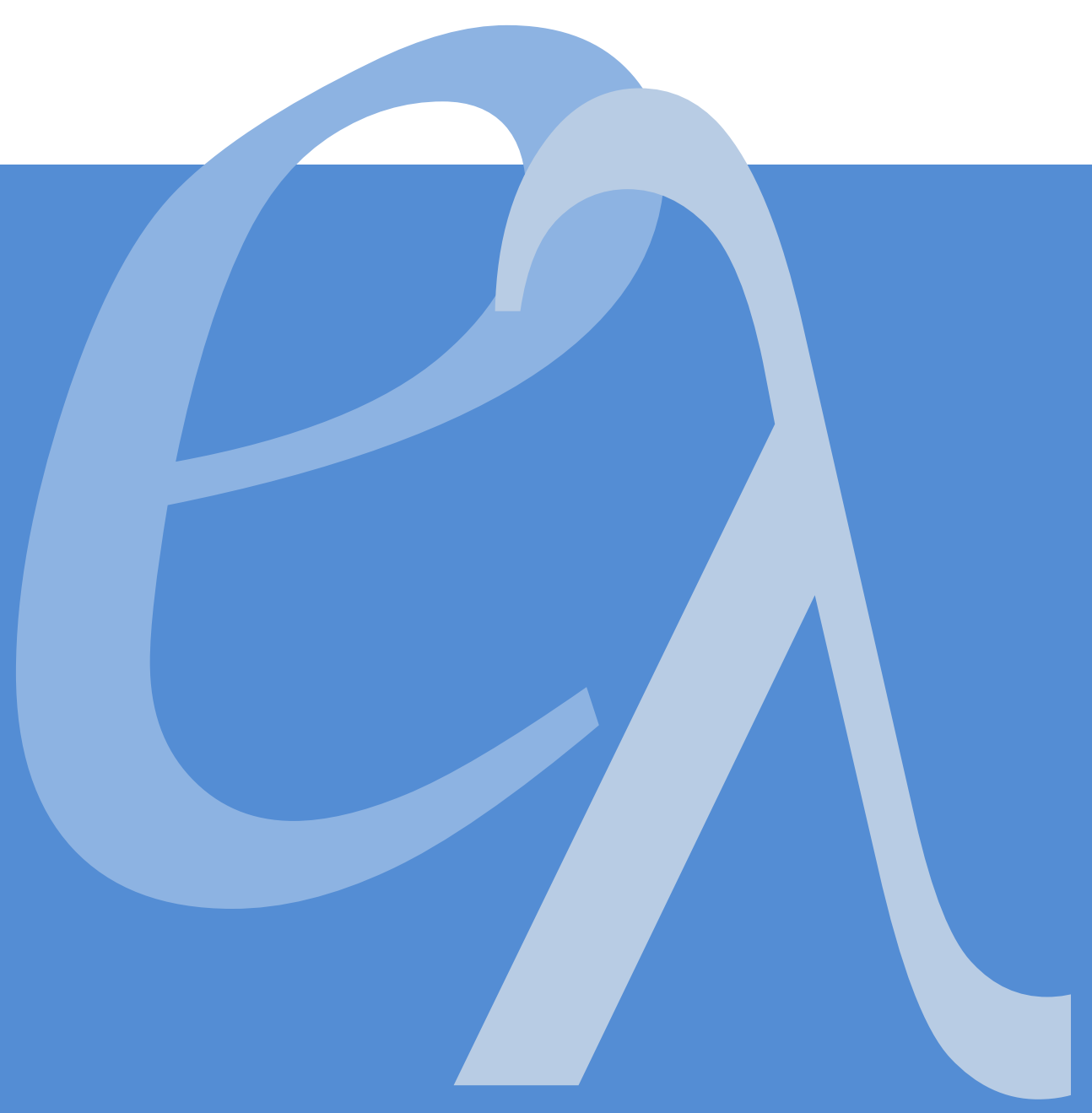




\begin{abstract}
Study presents two ideas of philosophy as a science as exposed both in David Hume's Treatise ("science of man“ or "science of human nature“) and Enquiry („mental geography“ or "science of operations of mind“) with intent to make explicit fact, that former leads to philosophical analysis of time, the later to absence of this kind of analysis. Study is a contribution to the new Hume debate in sense of "Treatise turn" and reminder of 270th anniversary of Treatise first publication.
\end{abstract}

\title{
Abstrakt
}

Studie prezentuje dvě ideje filosofie jako vědy v Traktátu („věda o člověku“ či „věda o lidské přirozenosti“) a Zkoumáních („mentální geografie“ či „věda o úkonech mysli“) Davida Huma a dokládá na předvedení tematizace času v 1. knize Traktátu a s odkazy na Zkoumání, že v prvním případě vede k plastické analýze času, v druhém případě pak $\mathrm{k}$ její absenci. V neposlední řadě je studie inspirací k novému promýšlení Humova filosofického odkazu s akcentem na Traktát, jehož 270. výročí vydání si v tomto roce připomínáme. 
V roce 2009 si připomínáme 270. výročí vydání A Treatise of Human Nature (dále jen Traktát), fakticky prvního a zároveň filosoficky nejkomplexnějšího díla Davida Hume, které je považováno za vůbec nejsytematičtější a nejobsáhlejší filosofické pojednání, které kdy vzešlo na půdě "english-speaking philosophy". Studie si klade za úkol předvést Humovy ideje filosofie jako vědy tak, jak byly zformulovány v Traktátu z roku 1739 a z An Enquiry Concerning Human Understanding (dále jen Zkoumánî), kterým se dostalo jedenácti vydání (první 1748, poslední posmrtné z roku 1777) a na rozdíl od Traktátu i tří českých překladů. Pozoruhodným, v literatuře opomíjeným faktem je, že realizace ideje filosofie jako vědy v Traktátu s sebou nese výslovnou tematizaci času, realizace ideje filosofie jako vědy ve Zkoumáních s sebou pak nese absenci takové výslovné tematizace. Přitom je tematizace či „teorie“ času ve „filosofickém systému“ Davida Hume považována za jednu z jeho nejtemnějších, nejméně srozumitelných, nejproblematičtějších a nejobtížněji vysvětlitelných "součástí“ a svědectví o tom nacházíme jak při pohledu do dějin, tak i do současných pokusů o její interpretaci. ${ }^{1}$ Je inspirací pro filosofie tak odlišné ražby jako Kantovu, ${ }^{2}$ Husserlovu či zakladatelů "logického pozitivismu“ a současné "analytické filosofie“". ${ }^{3}$ Jako celek má studie $\mathrm{v}$ neposlední řadě poukázat na potřebu jistého návratu $\mathrm{k}$ myšlenkovému bohatství a plasticitě filosofického výkazu, kterou Hume prezentuje právě v Traktátu, a to s nadějí, že to rozšǐrí náš pohled až př́liš často upjatý na jeho Zkoumání.

\section{Idea "vědy o člověku" ("vědy o lidské přirozenosti") a nástin tematizace času v 1. knize Traktátu ${ }^{4}$}

Chceme-li zahlédnout základní kontury Humovy ideje "vědy o člověku" a následně nechat vystoupit $\mathrm{v}$ tomto kontextu tematizaci času, musíme se nejdříve dotázat, jak Hume sám formuluje cíl svého díla, jak rozumí svému úkolu. Význačnou stopu nám poskytuje již Advertisement $\mathrm{k}$ Traktátu, kde nás Hume v této věci odkazuje na Introduction a zároveň poprvé představuje svoji vizi celkového rozvrhu díla, ${ }^{5}$

\footnotetext{
${ }^{1}$ Příznačný titul nese monografie Donalda L. M. Baxtera z roku 2008: Hume's Difficulty (Time and Identity in the Treatise).

${ }^{2}$ Exponováno nově např. v monografii HenRy A. AllisonA, Custom and Reason (A Kantian Reading of the First Book of the Treatise), Oxford: Oxford University Press, 2008.

${ }^{3}$ R. READ a K. A. RichMAN (eds.), The New Hume Debate, London and New York: Routledge, 2006.

4 Tato část studie vznikla V rámci řešení projektu „Filosofické předpoklady antropologického významu času“ (GAČR 401/09/0480) Grantové agentury České republiky (př́ijemce FHS UK Praha) a je upravenou verzí autorova př́spěvku do kolektivní monografie: T. KUNCA, „Čas, jak se ukazuje lidské mysli (v Traktátu Davida Huma)", in Časovost a smrtelnost (Studie k časové konstituci lidské existence), Praha: TOGGA, 2009 ( $\mathrm{v}$ tisku).

5 "My design in the present work is sufficiently explain'd in the Introduction. The reader must only observe, that all the subjects I have there plann'd out to myself, are not treated of in these two volumes. The subjects of the Understanding and Passions make a compleat chain of reasoning by themselves; and I was willing to take advantage of this natural division, in order to try the taste of the public. If I have the good fortune to meet with success, I shall proceed to the examination of Morals,
} 
který byl dovršen jen zčásti. Celkový záměr díla je v Introduction představen v několika krocích a jistě nepřekvapí, že první krok tvoří literárně zdařilá a k široké čtenářské věřejnosti obrácená kritická expozice neutěšeného stavu dobového vědění, zejména filosofie. 6

V druhém kroku, bez dalšího zprostředkování, již přichází s tvrzením o evidenci toho, že všechny vědy se více či méně vztahují k lidské přirozenosti (human nature) a jsou v různém stupni závislé na "vědě o člověku“ (science of man), ${ }^{7}$ jindy hovoří o „vědě o lidské přirozenosti“ (science of human nature) ${ }^{8}$ a má přitom na mysli stejnou „vědu“. Na ní jsou do určité míry závislé dokonce i matematika (Mathematics), přírodní filosofie (Natural Philosophy) a přirozené náboženství (Natural Religion). I ty totiž spadají do rámce lidského poznání a jejich posouzení závisí na schopnostech a silách vlastních člověku. V následující pasáži se pak dostáváme k prvnímu místu, kde v Traktátu alespoň nepřímo zaznívá to, čemu Hume rozumí jako jednomu ze základních úkolů „vědy o člověku“. Tvrdí, že je nemožné odhadnout, jakého prokroku a změn v těchto vědách se můžeme nadít, pokud bychom byly důkladně obeznámeni s rozsahem a silou (extent and force) lidského rozumu či poznání (human understanding) a byli s to vysvětlit jak podstatu idejí, které používáme (the nature of

Politics, and Criticism; which will compleat this Treatise of Human Nature. The approbation of the public I consider as the greatest reward of my labours; but am determined to regard its judgment, whatever it be, as my best instruction." (T, Advert.) Citace je z díla

D. Hume, A Treatise of Human Nature: Two volume set (Clanderon Edition of the Works of David Hume), Volume 1, Oxford: Oxford University Press, 2007. Při citacích se budu držet normy běžné v humovských studiích, kdy se v závorce uvede T (Treatise) následovaný (s vyjímkou Advertisementu= Advert. a Introduction = Intro.) číslem knihy, čílem oddílu, číslem kapitoly a číslem paragrafu ve tvaru "(T X.X.X.X)".

6 "Nothing is more usual and more natural for those, who pretend to discover anything new to the world in philosophy and the sciences, than to insinuate the praises of their own systems, by decrying all those, which have been advanced before them. And indeed were they content with lamenting that ignorance, which we still lie under in the most important questions, that can come before the tribunal of human reason, there are few, who have an acquaintance with the sciences, that would not readily agree with them. It is easy for one of judgment and learning, to perceive the weak foundation even of those systems, which have obtained the greatest credit, and have carried their pretensions highest to accurate and profound reasoning. Principles taken upon trust, consequences lamely deduced from them, want of coherence in the parts, and of evidence in the whole, these are every where to be met with in the systems of the most eminent philosophers, and seem to have drawn disgrace upon philosophy itself." (T, Intro.1)

7 "'Tis evident, that all the sciences have a relation, greater or less, to human nature: and that however wide any of them may seem to run from it, they still return back by one passage or another. Even Mathematics, Natural Philosophy, and Natural Religion, are in some measure dependent on the science of MAN; since the lie under the cognizance of men, and are judg'd of by their powers and faculties. 'Tis impossible to tell what changes and improvements we might make in these sciences were we thoroughly acquainted with the extent and force of human understanding, and cou'd explain the nature of the ideas we employ, and of the operations we perform in our reasonings." (T, Intro. 4)

8 Srov.: "I do not think a philosopher, who would apply himself so earnestly to the explaining the ultimate principles of the soul, would show himself a great master in that very science of human nature, which he pretends to explain, or very knowing in what is naturally satisfactory to the mind of man. " (T, Intro. 9) 
ideas we employ), tak aktivismů mysli (operations), které realizujeme v chodu úvah (při vyvozování závěrů) (the operations we perform in our reasonings). Existuje však ještě taková oblast věd, jež vykazuje bližší a těsnější vztah k „lidské přirozenosti“ a pro níž může mít "věda o člověku (lidské přirozenosti)“ ještě radikálnější důsledky. ${ }^{9}$ Vždyt' jediným cílem logiky (Logic) je vysvětlit jak principy a aktivismy (úkony) naší mohutnosti rozvažování (reasoning faculty), tak podstatu našich idejí. Etika (Morals) a estetika (Criticism) se týkají našeho vkusu a citů, politika (Politics) se zabývá lidmi jako sjednocenými do společnosti a v jejich vzájemné závislosti. Uvedená čtveřice věd pro Huma představuje souhrn téměř všeho, co pro nás může mít nějakou význačnost zdůvodňující potřebu poznání, či může vést at' již ke zdokonalení (improvement) nebo zkrášlení (ornament) lidské mysli (human mind). Z toho je tedy zřejmé, jakou orientaci je nutné pro filosofii zvolit. Bude to cesta do samotného centra či srdce věd, cesta $\mathrm{k}$ lidské přirozenosti samé (human nature itself). ${ }^{10}$ Jazykem vojenského stratéga nám říká, ovládněme lidskou přirozenost a rozšiřme své výboje jak na vědy, jež se dotýkají bezprostředních zájmů lidského života, ale úspěch v této věci nám umožní zaměřit se a dosáhnout úspěchu i v těch vědách, které jsou předmětem čisté intelektuální zvídavosti. Jazykem filosofa, již bez obraznosti, dospívá k silnému tvrzení, že není významné otázky, jejíž řešení není obsaženo ve vědě o člověku a neexistuje žádná otázka, v jejímž řešení můžeme dosáhnout alepoň určitého stupně jistoty, aniž bychom byli obeznámeni s touto vědou. Závěr nás již nepřekvapí. Činíme-li si nárok na vysvětlení principů lidské přirozenosti (principles of human nature), tak tím vlastně navrhujeme celý systém věd postavený na téměř zcela novém a zároveň jedině spolehlivém základě. Tak jako věda o člověku tvoří jedinou spolehlivou fundaci pro ostatní vědy, i ona sama musí být postavena na jediných

\footnotetext{
9 "If therefore the sciences of Mathematics, Natural Philosophy, and Natural Religion, have such a dependence on the knowledge of man, what may be expected in the other sciences, whose connexion with human nature is more close and intimate? The sole end of logic is to explain the principles and operations of our reasoning faculty, and the nature of our ideas: morals and criticism regard our tastes and sentiments: and politics consider men as united in society, and dependent on each other. In these four sciences of Logic, Morals, Criticism, and Politics, is comprehended almost everything, which it can any way import us to be acquainted with, or which can tend either to the improvement or ornament of the human mind." (T, Intro. 5)

10 "Here then is the only expedient, from which we can hope for success in our philosophical researches, to leave the tedious lingering method, which we have hitherto follow'd, and instead of taking now and then a castle or village on the frontier, to march up directly to the capital or center of these sciences, to human nature itself; which being once masters of, we may every where else hope for an easy victory. From this station we may extend our conquests over all those sciences, which more intimately concern human life, and may afterwards proceed at leisure to discover more fully those, which are the objects of pore curiosity. There is no question of importance, whose decision is not comprised in the science of man; and there is none, which can be decided with any certainty, before we become acquainted with that science. In pretending, therefore, to explain the principles of human nature, we in effect propose a compleat system of the sciences, built on a foundation almost entirely new, and the only one upon which they can stand with any security." (T, Intro. 6)
} 
spolehlivých základech, které máme k dispozici, z Humova hlediska to znamená, že musí být založena na zkušenosti (experience) a pozorování (observation). ${ }^{11}$

Zamýšlený rozvrh Traktátu, nebo pro náše účely lépe, celková podoba Humova projektu vypracování "vědy o člověku" ("science of man" či "science of human nature"), tedy filosofické antropologie jako vědy, má následující skladbu:

\section{Of the Understanding O rozumu}

2. Of the Passions O vášních

3. Of the Morals O etice

4. Of the Politics O politice

5. Of the Criticism O estetice

Finální podoba Traktátu, jak vyšla v letech 1739-40, se sestává ze tří knih a nutno dodat, že analýza času se slavnými (a pro mnohé i temnými) pasážemi z I. knihy (Of the Understanding) nevyčerpává a další „významová vrstva“ na nás čeká v II. knize (Of the Passsions), kdy je „rozum“ viděn jako specifická „vášeň“. Možná právě odtud (tematizujeme-li „od vášní“) bude možno získat půdu, na níž se téma času specificky vyostří a následně najde svoji „aplikaci“ při analýzách lidského jednání ve III. knize (Of Morals). Ve studii se však omezíme na stručný nástin tematizace času z I. knihy (Of the Understanding). Humova Zkoumání totiž nesou nejen podobný titul, ale z věcného hlediska se zabývají stejným tématem, které nechají vystoupit nikoliv již v kontextu široké ideje "vědy o člověku", ale ideje filosofie jako vědy ve smyslu "mental geography".

Téma času v I. knize explicitně zaznívá až v titulu 2. části ( $O f$ the ideas of space and time), nicméně se začíná připravovat a jeho ladění se $\mathrm{v}$ jistém smyslu rozhodne $\mathrm{v} 1$. části (Of the ideas, their origin, composition, connexion, abstraction, etc.). Nelze pominout zejména určení, jichž se nám dostává ve 4 . kapitole (Of the connexion or association of ideas) v kontextu výkladu principů asociace (sdružování) idejí. ${ }^{12}$ Jedním z nich je

11 "And as the science of man is the-only solid foundation for the other sciences, so the only solid foundation we can give to this science itself must be laid on experience and observation." (T, Intro. 7) 12 , As all simple ideas may be separated by the imagination, and may be united again in what form it pleases, nothing would be more unaccountable than the operations of that faculty, were it not guided by some universal principles, which render it, in some measure, uniform with itself in all times and places. Were ideas entirely loose and unconnected, chance alone would join them; and it is impossible the same simple ideas should fall regularly into complex ones (as they Commonly do) without some bond of union among them, some associating quality, by which one idea naturally introduces another. This uniting principle among ideas is not to be considered as an inseparable connexion; for that has been already excluded from the imagination: Nor yet are we to conclude, that without it the mind cannot join two ideas; for nothing is more free than that faculty: but we are only to regard it as a gentle 
princip sousednosti (či silněji, doteku) v čase nebo místě (CONTIGUITY in time or place). Primární úlohu zde sehrává obraznost (imagination), ale ta musí být podle Huma k takovému způsobu představování (představení objektů jako dotýkajících se či sousedících v čase či prostoru) dovedena dlouho upevňovaným zvykem (custom) a s nutností, která je analogická nutnosti, s níž se smyslům podávají objekty jako dotýkající se (sousedící) v čase a prostoru. Obraznost tak při utváření představ objektů (nutně) spojuje (uvádí do vztahů) prostorové a časové „body“ (the parts of space and time). ${ }^{13}$ 5. kapitola 1 . části nese titul Of relations (mají se na mysli "relace idejí“) a Hume zde usiluje o vymezení základních zdrojů, z nichž čerpají všechny filosofické relace. ${ }^{14}$ Vymezuje sedm takových základních relací, kdy jako ona nejelementárnější je vymezena relace podobnosti (resemblance). Bez ní nemůže žádná filosofická relace existovat. ${ }^{15}$ Nejobecnější (nejuniverzálnější) je však relace identity (identity), následována (co do stupně univerzality) relacemi prostoru a času. $\mathrm{V}$ čem spočívá priorita univerzality relace identity? Autor ji připisuje zejména tomu, že identita je vlastní každému jsoucnu (being), jehož existence vykazuje nějaké trvání (duration). ${ }^{16}$ A právě motiv trvání se nám ukáže $\mathrm{v}$ dalším výkladu jako význačný pro

force, which commonly prevails, and is the cause why, among other things, languages so nearly correspond to each other; nature in a manner pointing out to every one those simple ideas, which are most proper to be united in a complex one. The qualities, from which this association arises, and by which the mind is after this manner conveyed from one idea to another, are three, viz. RESEMBLANCE, CONTIGUITY in time or place, and CAUSE and EFFECT. " (T, 1.1.4.1)

13 "I believe it will not be very necessary to prove, that these qualities produce an association among ideas, and upon the appearance of one idea naturally introduce another. 'Tis plain, that in the course of our thinking, and in the constant revolution of our ideas, our imagination runs easily from one idea to any other that resembles it, and that this quality alone is to the fancy a sufficient bond and association. 'Tis likewise evident that as the senses, in changing their objects, are necessitated to change them regularly, and take them as they lie contiguous to each other, the imagination must by long custom acquire the same method of thinking, and run along the parts of space and time in conceiving its objects. As to the connexion, that is made by the relation of cause and effect, we shall have occasion afterwards to examine it to the bottom, and therefore shall not at present insist upon it. It is sufficient to observe, that there is no relation, which produces a stronger connexion in the fancy, and makes one idea more readily recall another, than the relation of cause and effect betwixt their objects." $(\mathrm{T}, 1.1 .4 .2)$

${ }^{14}$ Nortonovi upozorňují, že Hume v pojetí relací rozlišuje přirozené (natural) relace idejí, které vznikají mimovolně, na základě působení principů asociace, a filozofické (philosophical). Ty vznikají na základě svévolného nebo záměrného rozhodnutí porovnat ideje. (D.F. NORTON a M.J. NORTON (eds.), „Editors' Annotations", in D. HumE, A Treatise of Human Nature: Two volume set (Clanderon Edition of the Works of David Hume), Volume 2, Oxford: Oxford University Press, 2007, s. 701.)

15,1 . The first is resemblance: And this is a relation, without which no philosophical relation can exist; since no objects will admit of comparison, but what have some degree of resemblance. But tho' resemblance be necessary to all philosophical relation, it does not follow, that it always produces a connexion or association of ideas. When a quality becomes very general, and is common to a great many individuals, it leads not the mind directly to any one of them; but by presenting at once too great a choice, does thereby prevent the imagination from fixing on any single object." $(\mathrm{T}, 1.1 .5 .3)$

16 "2. Identity may be esteem'd a second species of relation. This relation I here consider as applied in its strictest sense to constant and unchangeable objects; without examining the nature and foundation of personal identity, which shall find its place afterwards. Of all relations the most universal is that of identity, being common to every being whose existence has any duration." (T, 1.1.5.4) 
Humovo pojetí času. Relace prostoru a času pak představují nevyčerpatelný zdroj srovnání „objektů“ co do jejich vzdálenosti či odstupu (distance), sousednosti či dotyku (contiguous), nahoře (above), dole (below), před (before), po (after) atd. ${ }^{17}$

Základním místem pro interpretaci pojetí času u Huma je tradičně již zmíněná 2. část I. knihy Traktátu, diskusi vyvolávají zejména první tři kapitoly: 1. O nekonečné dělitelnosti našich idejí prostoru a času (Of the infinite divisibility of ideas of space and time), 2. O nekonečné dělitelnosti prostoru a času (Of the infinite divisibility of space and time) a 3. O dalších určeních našich idejí prostoru a času (Of the other qualities of our ideas of space and time). Oliver Johnson považuje celou tuto druhou část první knihy za nejtemnější z celé I. knihy Traktátu a zároveň upozorňuje, že přes svůj název v ní Hume tématu času až tolik pozornosti nevěnuje. ${ }^{18}$ Hlavním cílem je zde podle něj totiž výkaz rozporů a absurdností, $\mathrm{k}$ nimž vede dobová věda s předpokladem prázdného prostoru a matematika pracující s představou nekonečné dělitelnosti, a zároveň pokus o jejich řešení prostřednictvím aplikace teorie idejí vypracované v první části Traktátu. Pojednání o čase se tak (s výjimkou několika stránek v třetí kapitole) mohou jevit jako stručné dodatky k Humově tematizaci prostoru. ${ }^{19}$

Prostudujeme-li pečlivě text první kapitoly ( $O$ nekonečné dělitelnosti našich idejí prostoru a času), skutečně tam nenalezneme ani jeden explicitní odkaz k tématu času. Přesto zde zaznívá cosi, co je zřejmě pro Huma při jakýchkoli úvahách na téma času (at' již v přírodních vědách či vědách o lidském jednání) fundamentálnější než jakákoli explicitní zmínka či dodatek. Cosi, co konec konců i zdůvodňuje, proč autor podává téma času jako „dodatek“ či dokreslení tematizace prostoru. $S$ „nekonečnou dělitelností“ jsme na tom totiž stejně, jedná-li se o ideu prostoru nebo času.

Jakou podobu má Humův argument? ${ }^{20}$ Vychází z toho, že chápavost mysli (capacity of mind) má své meze (to se všeobecně připouští) a nikdy tedy nemůže dosáhnout plného a adekvátního pochopení (conception) nekonečnosti. To nám

17 "3. After identity the most universal and comprehensive relations are those of space and time, which are the sources of an infinite number of comparisons, such as distant, contiguous, above, below, before, after, etc." (T, 1.1.5.5)

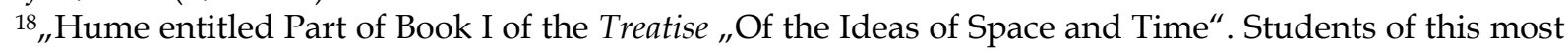
obscure Part of the Book are aware, however, that he spends little time in it on time." (O.A. JOHNSON, „Time and the Idea of Time“, in Hume Studies XV (1), 1989, s. 205.)

19 Tamt.

20 "Tis universally allow'd, that the capacity of the mind is limited, and can never attain a full and adequate conception of infinity: And tho' it were not allow'd, 'twou'd be sufficiently evident from the plainest observation and experience. 'Tis also obvious, that whatever is capable of being divided in infinitum, must consist of an infinite number of parts, and that 'tis impossible to set any bounds to the number of parts, without setting bounds at the same time to the division. It requires scarce any, induction to conclude from hence, that the idea, which we form of any finite quality, is not infinitely divisible, but that by proper distinctions and separations we may run up this idea to inferior ones, which will be perfectly simple and indivisible. In rejecting the infinite capacity of the mind, we suppose it may arrive at an end in the division of its ideas; nor are there any possible means of evading the evidence of this conclusion." (T, 1.2.1.2.) 
dokáže i prosté pozorování a zkušenost. Zároveň je zřejmé, že vše co má být dělitelné donekonečna se musí sestávat z nekonečného počtu součástí, a že je nemožné stanovit jakékoli meze počtu součástí, aniž bychom zároveň nestanovili meze dělení. Co z toho můžeme snadno odvodit? Že idea, kterou si o každé konečné věci (finite quality) utváříme, není nekonečně dělitelná, ale na základě vhodných aktů rozlišování (distictions) a třídění (separations) ji můžeme rozložit na jednodušší ideje, jež budou dokonale jednoduché a nedělitelné. Popíráme-li tedy neomezenou chápavost mysli, tak zároveň přepokládáme, že mysl může v dělení idejí dospět do nějakého konečného bodu. Na základě toho je pak pro Huma jisté, že obraznost (imagination) dospívá k minimu (reaches a minimum) a je s to si vytvořit ideu, u níž je nemyslitelné další dělení a jež nemůže být dále zredukována, aniž by nedošlo $\mathrm{k}$ její naprosté zkáze (total annihilation). ${ }^{21}$ Stejné pak platí i pro (v porovnání s idejemi z obraznosti ještě bezprostřednější) smyslové vjemy či imprese (impressions of the senses). I zde docházíme (např. zprostředkováním mikroskopem či dalekohledem) k onomu minimu, které nebylo pro odstup od objektu bezprostředně vnímatelné. ${ }^{22}$ Pro Huma nemůže být nic menšího (minute), než ideje vytvořené obrazností či vjemy našich smyslů, protože obě tyto "skupiny“ obsahů naší mysli se shodují v tom, že mohou dospět ke zmíněnému minimu, krajní mezi, kdy jsou dokonale jednoduché (perfectly simple) a nedělitelné (indivisible).23

\footnotetext{
21 "'Tis certain, that the imagination reaches a minimum, and may raise up to itself an idea, of which it cannot be diminish'd without a total annihilation. When you tell me of the thousandth and ten thousandth part of a grain of sand, I have a, distinct idea of these numbers and of their different proportions; but the images, which I form in my mind to represent the things themselves, are nothing different from each other, nor inferior to that image, by which I represent the grain of sand itself, which is supposed so vastly to exceed them. What consists of parts is distinguishable into them, and what is distinguishable is separable. But whatever we may imagine of the thing, the idea of a grain of sand is not distinguishable, nor separable into twenty, much less into a thousand, ten thousand, or an infinite number of different ideas." $(\mathrm{T}, 1.2 .1 .3)$

22 "It is the same case with the impressions of the senses as with the ideas of the imagination. Put a spot of ink upon paper, fix your eye upon that spot, and retire to such a distance, that, at last you lose sight of it; it is plain, that the moment before it vanished the image or impression was perfectly indivisible. It is not for want of rays of light striking on our eyes, that the minute parts of distant bodies convey not any sensible impression; but because they are removed beyond that distance, at which their impressions were reduced to a minimum, and were incapable of any farther diminution. A microscope or telescope, which renders them visible, produces not any new rays of light, but only spreads those, which always flowed from them; and by that means both gives parts to impressions, which to the naked eye appear simple and uncompounded, and advances to a minimum, what was formerly imperceptible." (T, 1.2.1.4)

${ }^{23}$ "We may hence discover the error of the common opinion, that the capacity of the mind is limited on both sides, and that it is impossible for the imagination to form an adequate idea, of what goes beyond a certain degree of minuteness as well as of greatness. Nothing can be more minute, than some ideas, which we form in the fancy; and images, which appear to the senses; since there are ideas and images perfectly simple and indivisible. The only defect of our senses is, that they give us disproportioned images of things, and represent as minute and uncompounded what is really great and composed of a vast number of parts." ( $\mathrm{T}, 1.2 .1 .5)$
} 
Název druhé kapitoly (O nekonečné dělitelnosti prostoru a času) na první pohled slibuje cosi jako obrat či posun ve výkazu od toho, jak se nám "prostor a čas“ podává, k tomu, jak jsou (s odpuštěním) „o sobě“. Hume je však dalek nějakého naivního "realismu“ či „objektivismu“ a říká jen to, že všude tam, kde jsou ideje adekvátními zpodobněními svých objektů či věcí (adequate representations of objects), tam jsou i všechny jejich relace, kontradikce či shody platné pro objekty či věci (applicable to the objects). A v tom nevidí nic menšího než základ veškerého lidského poznání. ${ }^{24}$ Co se prostě při srovnání idejí ukazuje (appears) jako nemožné či kontradiktorické, musí být bez dalšího považováno za skutečně (really) nemožné a vnitřně si odporující. ${ }^{25} \mathrm{Je}$ tedy zřejmé, že tato „maxima“ se vztahuje nejen na ideu prostoru, ale i času. A to lze doložit i tvrzením, podle něhož se všechny úvahy o prostoru vztahují i kčasu, nicméně musíme $\mathrm{k}$ nim přxičinit „dodatečný argument“ ${ }^{26} \mathrm{~A}$ právě tento „dodatečný argument“ je místem, kde explicitně hovoří o „esenci času“. ${ }^{27}$ Řečeno silně, čas dělá časem to, že jeho části či úseky (parts) následují jeden po druhé, ale žádný z nich, ač je jakkoli těsně svázán či sousedí s jiným, nikdy s ním nemůže koexistovat. Je to proň ze stejného důvodu, pro který se rok 1737 nemůže krýt či shodovat s rokem 1738. Každý úsek času či okamžik (moment) musí být jasně odlišitelný, následuje nebo předchází jiný úsek. Z toho pak vyvozuje, že „čas, jak jest" (time, as it exists) se musí sestávat $\mathrm{z}$ nedělitelných úseků (indivisible moments). Zdůvodnění je pro Huma zřejmé. Pokud bychom nikdy nebyli s to dosáhnout konce dělení času, a pokud by každý úsek času ve své následnosti nebyl zcela jedinečný a nedělitelný (perfectly single and indivisible), pak bychom čelili situaci, kdy zde máme nekonečný počet koexistujících úseků času (co-existent moments, or parts of time), a to, jak věří, může být chápáno jako př́ípad zcela zjevné kontradikce.

Nejobsáhlejší výklad tématu času ve smyslu „ideje času“ přináší třetí kapitola $(O$ dalších určeních našich idejí prostoru a času), která chce být aplikací principu

\footnotetext{
24 "Wherever ideas are adequate representations of objects, the relations, contradictions and agreements of the ideas are all applicable to the objects; and this we may in general observe to be the foundation of all human knowledge." ( $\mathrm{T}, 1.2 .2 .1)$

25 ,But our ideas are adequate representations of the most minute parts of extension; and through whatever divisions and subdivisions we may suppose these parts to be arrived at, they can never become inferior to some ideas, which we form. The plain consequence is, that whatever appears impossible and contradictory upon the comparison of these ideas, must be really impossible and contradictory, without any farther excuse or evasion." (Tamt.)

26 "All this reasoning takes place with regard to time; along with an additional argument, which it may be proper to take notice of." (T, 1.2.2.4)

27 "'Tis a property inseparable from time, and which in a manner constitutes its essence, that each of its parts succeeds another, and that none of them, however contiguous, can ever be co-existent. For the same reason, that the year 1737 cannot concur with the present year 1738 every moment must be distinct from, and posterior or antecedent to another. 'Tis certain then, that time, as it exists, must be compos'd of indivisible moments. For if in time we cou'd never arrive at an end of division, and if each moment, as it succeeds another, were not perfectly single and indivisible, there wou'd be an infinite number of co-existent moments, or parts of time; which I believe will be allow'd to be an arrant contradiction." (Tamt.)
} 
považovaného Humem za rozhodující i v tom smyslu, že má odstranit všechny spory týkající se podstaty idejí, tedy i ideje času. Onen slavný princip sice formuluje a uplatňuje již v 1. části I. knihy Traktátu, zde nám připomíná jeho jádro. ${ }^{28}$ Jedná se o známé diktum tvrdící, že imprese vždy předcházejí idejím a každá idea, s níž „operuje“ obraznost, se poprvé ukázala mysli ve formě imprese, která jí odpovídá. Ideje jsou v tomto smyslu jakési "odvozené imprese“ a právě svojí vazbou na „primární imprese“ získávají rys takové jasnosti a zřejmosti (clear and evident), jež dle Huma nepřipouští sporu. Nicméně jsou zde i četné ideje temné (obscure) natolik, že ani jejich "autor“ - produktivní mysl - není s to přesně zachytit jejich původ či podstatu (nature) a vnitřní skladbu (composition).

V prvním kroku „aplikace“ se nám předvádí idea času právě jako př́ípad abstraktní ideje a těleso vlastního výkazu je uvedeno vymezením toho, jak Hume rozumí abstraktním idejím. ${ }^{29}$ Ty chápe jako případ jednotlivých a v tom smyslu i určitých idejí, k nimž připojujeme obecné termíny a ony pak zastupují širokou paletu fenoménů a umožňují mysli uchopit ty objekty, které se v určitých ohledech podobají, v jiných jsou vzdáleny. Idea času je však specifická abstraktní idea jednak tím, že je odvozena z následnosti percepcí všeho druhu (jak z následností idejí, tak impresí, a v jejich rámci jak z impresí z reflexe, tak bezprostředních a jednoduchých smyslových vjemů), jednak její "síla reprezentativnosti“ je dokonce větší než u (abstraktní) ideje prostoru, a přitom je v představivosti (fancy) "reprezentována“ konkrétní jednotlivou ideou určité kvantity a kvality. ${ }^{30}$ Tak jako z rozestavení (či silněji, $\mathrm{z}$ „rozprostranění") viditelných a hmatatelných objektů (visible and tangible objects) získáváme ideu prostoru, z následnosti idejí a impresí získáváme ideu času. Hume se domnívá, že bez této následnosti se nám prostě čas sám (time alone) vůbec nemůže ukázat, a dokonce ani nemůže být myslí zaznamenán. ${ }^{31}$ Př́kladem mu je člověk upadlý do hlubokého spánku nebo intenzivně se zaobírající jednou myšlenkou či představou. $\mathrm{V}$ obou případech bude nevšímavý či netečný (insensible)

\footnotetext{
28 "No discovery cou'd have been made more happily for deciding all controversies concerning ideas, than that above-mention'd, that impressions always take the precedency of them, and that every idea, with which the imagination is furnished, first makes its appearance in a correspondent impression. These latter perceptions are all so clear and evident, that they admit of no controversy; tho' many of our ideas are so obscure, that 'tis almost impossible even for the mind, which forms them, to tell exactly their nature and composition. Let us apply this principle, in order to discover farther the nature of our ideas of space and time." (T, 1.2.3.1)

29 "All abstract ideas are really nothing but particular ones, consider'd in a certain light; but being annex'd to general terms, they are able to represent a vast variety, and to comprehend objects, which, as they are alike in some particulars, are in others vastly wide of each other." (T, 1.2.3.5)

30 "The idea of time, being deriv'd from the succession of our perceptions of every kind, ideas as well as impressions, and impressions of reflection as well as of sensations will afford us an instance of an abstract idea, which comprehends a still greater variety than that of space, and yet is represent'd in the fancy by some particular individual idea of a determinate quantity and quality." (T, 1.2.3.6)

31 "As it is from the disposition of visible and tangible objects we receive the idea of space, so from the succession of ideas and impressions we form the idea of time, nor is it possible for time alone ever to make its appearance, or be taken notice of by the mind." (T, 1.2.3.7)
} 
k času. V závislosti na tom, budou-li percepce následovat v rychlejším či pomalejším sledu, bude se v jeho obraznosti i samo trvání (duration) ukazovat jako delší nebo kratší. $^{32}$ Zmiňuje v tomto kontextu myšlenku Johna Locka o mezích (možnosti) našich percepcí, které jsou nám dány prvotní přirozeností a konstitucí mysli (original nature and constitution of the mind) a mimo něž žádný vliv vnějších objektů (external objects) na smysly nikdy nemůže urychlit či zpomalit naši mentální aktivitu (thought). ${ }^{33}$ Uvádí známý př́iklad s hořícími uhlíky. Když je před sebou dostatečně rychle otáčíme, vytváří smyslům obraz ohnivého kruhu, aniž by se zdálo, že je zde vůbec nějaký časový rozestup (interval of time) mezi jednotlivými otočkami. A důvod? Prostě proto, že je pro naše percepce nemožné následovat po sobě se stejnou rychlostí, s jakou může být pohyb propůjčen vnějším objektům. Ve všech případech, kdy nemůžeme zakusit následnost percepcí, nemáme podle Huma ani ponětí o čase (notion of time), i kdyby nakrásně reálná následnost (real succession) v objektu přítomna byla. ${ }^{34}$ Závěr nás již nepřekvapí. Čas se mysli nemůže ukázat ani sám (o sobě), ani ve spojení se stálým a neměnným objektem (steady und unchangeable object), ale vždy je zjištěn na základě nějaké vnímatelné (percepce umožňující) následnosti proměnlivých objektů. ${ }^{35}$ Aby tento závěr ještě více upevnil přichází s dalším argumentem, který se mu jeví jako naprosto přesvědčivý. ${ }^{36} \mathrm{~V}$ prvním kroku postuluje evidenci toho, že „čas nebo trvání“ (time or duration) - a povšimněme si, že "čas“ a "trvání" mu splývají vjedno - se sestává z různých úseků (different parts) - na jiném místě dokonce hovoří o „bodech“ (points), nebot' jinak bychom nemohli mít ponětí o kratším nebo delším trvání. Zároveň je stejně zřejmé, že tyto úseky/body nejsou koexistující, nebot' rys či vlastnost koexistence částí/bodů náleží rozprostraněnosti (extension) a je tím, co ji odlišuje od trvání. V druhém kroku

32 "A man in a sound sleep, or strongly occupy'd with one thought, is insensible of time; and according as his perceptions succeed each other with greater or less rapidity, the same duration appears longer or shorter to his imagination." (Tamt.)

33 "It has been remark'd by a great philosopher, that our perceptions have certain bounds in this particular, which are fixed by the original nature and constitution of the mind, and beyond which no influence of external objects on the senses is ever able to hasten or retard our thought." (Tamt.)

34 "If you wheel about a burning coal with rapidity, it will present to the senses an image of a circle of fire; nor will there seem to be any interval of time betwixt its revolutions; meerly because it is impossible for our perceptions to succeed each other with the same rapidity, that motion may be communicated to external objects. Wherever we have no successive perceptions, we have no notion of time, even though there be a real succession in the objects." (Tamt.)

35 "From these phenomena, as well as from many others, we may conclude, that time cannot make its appearance to the mind, either alone, or attended with a steady unchangeable object, but is always discover'd some perceivable succession of changeable objects.“ (Tamt.)

36 "To confirm this we may add the following argument, which to me seems perfectly decisive and convincing. 'Tis evident, that time or duration consists of different parts: For otherwise we cou'd not conceive a longer or shorter duration. It is also evident, that these parts are not co-existent: For that quality of the co-existence of parts belongs to extension, and is what distinguishes it from duration. Now as time is compos'd of parts, that are not coexistent: an unchangeable object, since it produces none but coexistent impressions, produces none that can give us the idea of time; and consequently that idea must be deriv'd from a succession of changeable objects, and time in its first appearance can never be sever'd from such a succession." (T, 1.2.3.8) 
dovozuje, je-li čas složen z úseků, jež nejsou koexistentní a neproměnlivý objekt vyvolává pouze koexistentní imprese, pak nevyvolává nic, co by nám mohlo dát ideu času. V třetím kroku může důkaz uzavřít. Důsledkem výše uvedeného je to, že idea času musí být odvozena z následnosti stavů proměnlivých objektů (či jinak, objektů podléhajících změně) a čas, tak jak se nám prvotně ukazuje (time in its first appearance), nikdy nemůže být od této následnosti oddělen.

Tematizace času, jak se ukazuje naší mysli, tímto závěrem nekončí. Čas, jak se nám prootně ukazuje či podává, nemůže být od sukcese objektů podléhajících změně oddělen, ale Hume jde dál a ptá se, zda čas může být myslí pojmut, aniž bychom (zároveň) myslí nepojímali sukcesi objektů, a zda sám (o sobě, bez asistence sukcese objektů) může v obraznosti vytvořit zřetelnou (a tedy i jasně odlišitelnou) ideu. ${ }^{37}$ Takovým tázáním nás přibližuje k vyvrcholení tematizace času v I. knize Traktátu.

Po krátké předehře na téma různosti a rozlišitelnosti dospívá Hume $\mathrm{k}$ tomu, že idea času není odvoditelná z jednotlivé imprese smíšené s jinými impresemi a je od nich zřetelně odlišitelná, ale vzniká ze způsobu (arises altogether from the manner), v jakém se imprese ukazují mysli, aniž by se tím stala jednou z impresí. ${ }^{38}$ Uvažme, že pět tónů zahraných na flétnu nám dává impresi a ideu času. To však podle Huma neznamená, že čas je nějakou šestou impresí, která se sama podává sluchu nebo jinému smyslu. Těchto pět tónů prezentujících se mysli tímto specifickým zpo̊sobem nevyvolává v mysli ani žádné hnutí či emoci (emotion), ani žádný pocit (affection), jež by $\mathrm{v}$ mysli nechali vyrůst novou ideu. ${ }^{39}$ Zde mysl může zaznamenat jen způsobu (manner), v jakém se ty různé tóny ukazují a může jej následně zohlednit, aniž by při tom musela zohledňovat ony jednotlivé tóny a zároveň může ten způsob (ukazování se) spojit s libovolným objektem. Mysl nikdy nebude mít pojem o čase, aniž by neměla ideje objektů, nebot' čas se neukazuje jako nějaká specifická primární imprese a není ničím mimo různé ideje, imprese nebo objekty, které jsou určitým způsobem uspořádány. A ten způsob uspořádání je, že ideje, imprese nebo objekty po sobě následují. ${ }^{40}$

37 „Having therefore found, that time in its first appearance to the mind is always conjoin' $\mathrm{d}$ with a succession of changeable objects, and that otherwise it can never fall under our notice, we must now examine whether it can be conceiv'd without our conceiving any succession of objects, and whether it can alone form a distinct idea in the imagination." ( $T, 1.2 .3 .9)$

38 "The idea of time is not derived from a particular impression mix'd up with others, and plainly distinguishable from them; but arises altogether from the manner, in which impressions appear to the mind, without making one of the number." ( $\mathrm{T}, 1.2 .3 .10)$

39 "Five notes play'd on a flute give us the impression and idea of time; tho' time be not a sixth impression, which presents itself to the hearing or any other of the senses. Nor is it a sixth impression, which the mind by reflection finds in itself. These five sounds making their appearance in this particular manner, excite no emotion in the mind, nor produce an affection of any kind, which being observ'd by it can give rise to a new idea." (Tamt.)

40 "The ideas of some objects it certainly must have, nor is it possible for it without these ideas ever to arrive at any conception of time; which since it, appears not as any primary distinct impression, can 
Na závěr ještě podejme alespoň stručnou odpověd' na otázku po tom, na základě jaké představy podle Huma uplatňujeme ideu času dokonce i na ty objekty, které nepodléhají změně. ${ }^{41}$ Již jsme viděli argumentaci dokládající to, že je nemožné odkázat na impresi, z níž je odvozena idea času, bez předpokladu objektu vykazujícího změny. Jsou však takové jevy (appearances), jež vedou naši představivost $\mathrm{k}$ tomu, že ideu času máme i v tomto př́ípadě. Jaký fenomén má Hume na mysli? Můžeme zaznamenat nepřetržitou sukcesi percepcí v naší mysli, a právě na jejím základě jsme vždy (již) „vybaveni“ ideou času, čas je vždy při nás. ${ }^{42}$

\section{Idea "mentální geografie“ a (absence) výslovné tematizace času ve Zkoumáních}

Humova idea filosofie jako vědy ve Zkoumáních se opírá o přesvědčení, že „není bezvýznamným úkolem vědy znát různé úkony mysli (the different operations of the mind)“ a ono "znát" je blíže specifikováno jako "rozdělit je a zařadit pod patřičná záhlaví a upravit všechen ten zdánlivý nepořádek, ve kterém žijí, když se stávají předmětem úvah a zkoumání. Tento výklad o pořádání a rozlišování, který nemá smysl, když se týká vnějších těles (external bodies), tj. předmětů našich smyslů (the objects of our senses), nabývá cenu, když se zaměříme na úkony mysli (operations of the mind) podle obtíží a námahy, s nimiž se přitom setkáváme." Výsledkem takto orientovaného zkoumání může být alespoň jakýsi „duševní zeměpis (mental geography)“ nebo „vymezení různých částí a mohutností mysli“. ${ }^{43}$

plainly be nothing but different ideas, or impressions, or objects dispos'd in a certain manner, that is, succeeding each other." (Tamt.)

${ }^{41}$ Pro odpověd' se musíme vypravit až na samotný závěr 5. kapitoly 2. části I. knihy Traktátu, kde se věnuje námitkám vzneseným proti jeho teorii.

42 "But tho' it be impossible to shew the impression, from which the idea of time without a changeable existence is deriv'd; yet we can easily point out those appearances, which make us fancy we have that idea. For we may observe, that there is a continual succession of perceptions in our mind; so that the idea of time being for ever present with us; when we consider a stedfast object at five-a-clock, and regard the same at six; we are apt to apply to it that idea in the same manner as if every moment were distinguished by a different position, or an alteration of the object. The first and second appearances of the object, being compar'd with the succession of our perceptions, seem equally removed as if the object had really changed. To which we may add, what experience shews us, that the object was susceptible of such a number of changes betwixt these appearances; as also that the unchangeable or rather fictitious duration has the same effect upon every quality, by encreasing or diminishing it, as that succession, which is obvious to the senses. From these three relations we are apt to confound our ideas, and imagine we can form the idea of a time and duration, without any change or succession." $(\mathrm{T}, 1.2 .5 .29)$

43 "It becomes, therefore, no inconsiderable part of science barely to know the different operations of the mind, to separate them from each other, to class them under their proper heads, and to correct all that seeming disorder, in which they lie involved, when made the object of reflection and enquiry. This task of ordering and distinguishing, which has no merit, when performed with regard to external bodies, the object of our senses, rises in its value, when directed towards the operations of the mind, in proportion to the difficulty and labour, which we meet with in performing it. And if we can go no 
V dalším kroku Hume brání program „vědy o úkonech ducha" před nařčením z toho, že je "nejistá a chimérická“44 (jinak řečeno: "metafysická” ve smyslu „falešné, nepravé metafysiky“). „Není pochyby o tom, že duch je vybaven několika mohutnostmi a schopnostmi, že tyto mohutnosti se od sebe liší, že to, co vnímáme bezprostředním postřehem (immediate perception) jako různé, můžeme být rozlišeno i reflexí (reflection) a že je tedy pravda i nepravda ve všech výrocích o té věci; pravda i nepravda, která neleží mimo dosah lidského rozumu (human understanding)." 45 Kde se nachází pramen oné „jistoty a nepochybnosti“? "Jsou tu četná zřejmá rozlišení toho druhu jako mezi vůlí (the will) a rozumem, obrazivostí (the imagination) a vášněmi (passions), jež spadají do chápavosti_každé lidské bytosti; ale jemnější a filosofičtější rozlišení jsou neméně skutečná a jistá, i když hưřre pochopitelná." ${ }^{46}$ Věda, která má být podána čerpá svoji legitimitu z korespondence s lišením (samo)zřejmým „každé lidské bytosti“. Bude sice "filosofičtějši”, "hưřre pochopitelná", ale nikoli pohybující se na půdě překračující chápavost „každé lidské bytosti".

Ve třetím kroku se program "vědy o úkonech ducha“ odvolává nikoli na "chápavost každé lidské (= základního lišení úkonů ducha schopné) bytosti“, ale na nověkou přírodovědu. Hume se táže, zda lze ve „vědě o úkonech lidského ducha“ dosíci stejné úrovně vědění jako v „úspěšné přírodovědě“. „Nelze doufat, že filosofie ... aspoň do jisté míry objeví ty tajné vzpruhy a principy, jimiž je lidská mysl řízena ve svých úkonech?“47 Jako př́iklad oné „úspěšné vědy“ je citována astronomie. "Astronomové se dlouho spokojovali s tím, že z jevů dokazovali skutečné pohyby, řád a velikost nebeských těles, až se našel filosof, který patrně na základě velmi úspěšného přemýšlení stanovil také zákony a síly, jimiž se řídí a spravují oběhy planet. “48 Nejinak tomu bylo podle Huma i při objevech dotýkajících se jiných oblastí přírody. Na základě toho usuzuje: „A budeme-li se stejnou způsobilostí a opatrností postupovat při svém zkoumání duševních mohutností a jejich uspořádání, můžeme doufat ve stejný úspěch. “49

farther than this mental geography, or delineation of the distinct parts and powers of the mind, it is at least a satisfaction to go so far; and the more obvious this science may appear (and it si by no means obvious) the more contemptible still must the ignorace of it be esteemed, in all pretenders to learning philosophy." D. HuME, An Enquiry Concerning Human Understanding (The Clanderon Edition of the Works of David Hume), Oxford: Oxford University Press, 2000, s. 10 (dále citováno jako EHU, s. ...) Srovnej s D. HuME, Zkoumání lidského rozumu, Praha: Svoboda, 1972 (překl. V. Gaja), s. 38-39 (dále citováno jako Zkoumání (G), s. ...) a D. HuME, Zkoumání o lidském rozumu, Praha: Svoboda, 1996 (překl.

J. Moural), s. 33 (dále citováno jako Zkoumání (M), s. ...).

${ }^{44}$ EHU, s. 10; Zkoumání(G), s. 39; Zkoumání (M), s. 33.

${ }^{45}$ EHU, s. 10-11; Zkoumání (G), s. 39; Zkoumání (M), s. 34.

46 EHU, s. 11; Zkoumání(G), s. 39; Zkoumání (M), s. 34.

${ }^{47}$ EHU, s. 11; Zkoumání (G), s. 40; Zkoumání (M), s. 34.

${ }^{48}$ EHU, s. 11; Zkoumání (G), s. 40; Zkoumání (M), s. 34-35.

${ }^{49}$ EHU, s. 11; Zkoumání (G), s. 40; Zkoumání (M), s. 35. 
Ve čtvrtém kroku pak Hume přichází s "filosofickou hypotézou“, která bude orientovat jeho výzkum „úkonů mysli“, a o níž - jakožto o hypotéze filosofie jako vědy - nemůže být rozhodnuto před "pečlivým pokusem“ (!). Humova „hypotéza“ zní: „Je pravděpodobné, že jeden úkon a princip ducha závisí na druhém, který se zase dá převést na obecnější a univerzálnější. A jak daleko tato zkoumání povedou, těžko můžeme před pečlivým pokusem, ba dokonce i po něm, přesně říci. “50

$\mathrm{V}$ pátém kroku dochází $\mathrm{k}$ vyjádření toho, jak Hume rozumí povaze výsledku zkoumání. "At' nás tato zkoumání stojí námahu sebevětší, můžeme považovat za dostatečnou odměnu - nejen pokud se týká prospěchu, nýbrž i uspokojení - že takto rozmnožujeme zásobu vědomostí (we can make any addition to our stock of knowledge) o věcech tak nesmírně důležitých." 51

Pokusme se ve stručnosti shrnout námi stylizované "kroky“ Humovy „metodologické úvahy“ ve Zkoumáních. Před filosofii jako vědu je postaven úkol "znát různé úkony ducha“, kdy ono „znát" je zprvu identifikováno s „rozdělit a zařadit", učinit výklad o "pořádání a rozlišování“. Výsledek takového zkoumání pak vystupuje jako svého druhu „duševní zeměpis“. Ono "pořádání a rozlišování“ však není něčím vystupujícím na půdě „abstraktní spekulace“, ale opírá se o "zřejmá rozlišení", která spadají do chápavosti každého člověka. Představa o nové disciplíně (jejím cíli a metodě) je následně blíže určena Humovým náhledem na novověkou přírodovědu. Tak jako astronomie (a i ostatní úspěšné přírodní vědy) měla by nová disciplína doufat v to, že (alespoň do jisté míry) objeví „tajné vzpruhy a principy jimiž je lidský duch řízen ve svých úkonech“. Podmínkou úspěchu pak je "aplikace“ metody (v širokém smyslu slova), která dovedla přírodní vědy $\mathrm{k}$ úspěchu. Musíme tedy při zkoumání úkonů lidského ducha, duševních mohutností a jejich uspořádání postupovat se "stejnou zpơsobilostí a opatrností" jako úspěšné přírodní vědy. Abychom mohli takto postupovat, musíme být orientováni hypotézou a konat pokusy. Hume je při svém zkoumání směřujícím k objevení „tajných vzpruh a principů jimiž je lidský duch řízen ve svých úkonech“ orientován nejen předpokladem (samo)zřejmosti základního rozlišení (identifikace) úkonů ducha, ale i "hypotézou“ o vzájemné závislosti a převoditelnosti úkonů a principů ducha (připomeňme si: "Je pravděpodobné, že jeden úkon a princip ducha závisí na druhém, který se zase dá převést na obecnější a univerzálnější.“). Jak daleko se ( orientováni touto hypotézou) dostaneme, těžko před „pečlivým pokusem, ba dokonce i po něm, přesně říci“. Uspokojujícím výsledkem takového "pokusu“ pak bude rozmnožení „zásoby vědomostí". Něco bude přičiněno, přidáno $\mathrm{k}$ rostoucímu objemu, zásobě vědomostí, a to zejména

50 EHU, s. 11-12; Zkoumání(G), s. 40-41; Zkoumání (M), s. 35.

51 EHU, s. 12; Zkoumání (G), s. 41-42; Zkoumání (M), s. 36. 
díky novověké přírodovědě. Ono „něco“ je tedy předpokládáno jako svým statutem korespondující s poznatky novověké přírodovědy.

Humovy úvahy o filosofii jako vědě v oboru „úkonů lidské mysli“ jsou provázeny přesvědčením o prospěšnosti nově koncipované disciplíny pro lidstvo. Autor nešetří patosem při obhajobě věci své nové vědy: „Nejpříjemnější a nejneškodnější životní cesta vede alejemi vědy a učenosti a kdo odstraní z této cesty nějaké překážky nebo otevře nový výhled, měl by být považován za dobrodince lidstva.“ 52 Nešetří ani kritickým vzmachem stírajícím obludu "falešné metafyziky": "V tom také spočívá nejoprávněnější a nejpřijatelnější námitka proti velké části metafyziky, že to vlastně není věda, že vzniká bud' z marného úsilí lidské ješitnosti nebo $\mathrm{z}$ podvodu lidových pověr, které se nemohou hájit na otevřeném poli, pěstují proto nedotknutelné trní, aby zakryly a chránily své slabiny. Tito lupiči zahnáni z otevřeného pole utíkají do lesa a číhají, jak by vpadli do nějakého nestřeženého otvoru ducha a zdolali ho náboženskými předsudky a strachem."53 S trochou nadsázky snad můžeme říci, že Hume se staví do role strážce, rytíře ochraňujícího zdravý rozum a zkušenost aktivního člověka novověku. Do štítu si vepsal motto, jež mu napověděla sama příroda: „Měj si vášeň pro vědu, říká ( prŕíroda, T.K.), ale at' je tvá věda lidská a taková, aby se přímo vztahovala ke společnosti a činnosti. Zakazuji abstraktní myšlení a hluboká zkoumání a přísně tě potrestám zádumčivostí, kterou vyvolávají, bezmeznou nejistotou, do níž tě zaplétají, a chladným přijetím, jehož se dostane tvým objevům, když je uveřejníš. Bud' filosofem, ale při vší filosofii bud' především stále člověkem.“ 54

Uskutečnit zkoumání směřující k podání "duševního zeměpisu“, k objevení „tajných vzpruh a principů jimiž je lidská mysl řizena ve svých úkonech", k rozmnožení „zásoby vědomostí" znamená také pokusit se „objasnit předměty, jejichž nejistota odrazovala lidi moudré a temnota lidi nevědomé."55 Zkoumání, jehož výtěžkem bude pro novověkou filosofii klasická fixace struktury zkušenosti a které je ve svém celku vyzdvižením zkušenosti jako svébytného výzkumného tématu, se samo výslovně chápe jako „podkopávání základi̊ nesrozumitelné filosofie“ („falešné metafyziky“). "Jsme rádi, když dovedeme sloučit meze různých filosofií tím, že spojíme hluboké zkoumání s jasností a pravdu s novostí. A jsme ještě radši, když tímto lehčím filosofováním můžeme podkopávat základy nesrozumitelné filosofie, která dosud sloužila jako útočiště pověry a ochrana nesmyslu a hlouposti.“ 56

\footnotetext{
52 EHU, s. 8-9; Zkoumání (G), s. 36; Zkoumání (M), s. 30.

53 EHU, s. 9; Zkoumání(G), s. 36-37; Zkoumání (M), s. 30-31.

${ }^{54}$ EHU, s. 7; Zkoumání (G), s. 33-34; Zkoumání (M), s. 27-28.

55 EHU, s. 12; Zkoumání (G), s. 37; Zkoumání (M), s. 42.

56 EHU, s. 12; Zkoumání (G), s. 37; Zkoumání (M), s. 42.
} 
Realizační podoba Humovy „vědy o úkonech lidské mysli“ či „zeměpisu mysli“ je dobře známa. Zkoumání se sestávají z dvanácti kapitol a není naším cílem provést detailní srovnání s rozvrhem 1. knihy Traktátu. V obou dílech začíná vlastní výklad "prvních pojmů a principů vědy" stejně. V Traktátu jim Hume věnuje 1. část Of ideas, their origin, composition, connexion, abstraction etc. a $\mathrm{v}$ sedmi kapitolách (1. Of the origin of our ideas, 2. Division of the subject, 3. Of the ideas of the memory and imagination, 4 . Of the connexion ot association of ideas, 5 . Of relations, 6 . Of modes and substances, 7. Of abstract ideas) podává jejich plastický výklad. Ve Zkoumáních je takový výklad sevřen do dvou stručných kapitol (2. Of the Origin of Ideas, 3. Of the Association of Ideas). Idea „vědy o člověku“ (sceince of man) či "vědy o lidské přirozenosti“ (science of human nature) v Traktátu vedla Huma k tomu, že mu jako nutnost vystoupila tematizace času, a to nejen v 1. knize Of the Understanding, ale samostatnou kapitolu najdeme i v knize 2. Of Passions. Tematizace času (a prostoru) dokonce představuje hned druhý krok následující po vymezení základních pojmů a principů vědy. Druhá část 1 . knihy Traktátu má titul Of the ideas of space and time a sestává se ze šesti kapitol (1. Of the infinite divisibility of our ideas of space and time, 2. Of the infinite divisibility of space and time, 3. Of the other qualities of our ideas of space and time, 4. Objections answer'd, 5. The same subject continu'd, 6. Of the idea of existence, and of external existence). Ve Zkoumáních však nepředstavuje tematizace času (a prostoru) druhý krok v provedení „vědy o úkonech lidské mysli“ či "zeměpisu mysli“, ten je nahrazen výkladem na téma skeptických pochybností o úkonech rozumu (4. Sceptical Doubts concerning the Operations of the Understanding). Výslovné tematizaci času není věnována ani žádná z následujích kapitol a v celém díle najdeme pouze několik odkazů, na jejichž základě nemůžeme soudit, jak se čas ukazuje lidské mysli v Humových Zkoumáních. ${ }^{57}$ Absence výslovné tematizace času ve Zkoumáních je nezanedbatelným rozdílem oproti Traktátu, pravděpodobně i svědectvím toho, že idea filosofie jako vědy doznala jistého významového posunu. $\mathrm{V}$ neposlední řadě je i výzvou k novému promýšlení Humova filosofického odkazu, pokud je tento pro nás stále omezen na zažitá interpretační schámata odvozená z důvěrné obeznámenosti s jeho An Enquiry concerning Human Understanding.

${ }^{57}$ EHU, s. 103, 107, 109, 116 a 120. 


\section{Bibliography}

H.E. Allison, Custom and Reason in Hume (A Kantian Reading of the First Book of the Treatise), Oxford: Oxford University Press, 2008.

A.C. BAIER, A Progress of sentiments: Reflections on Hume's Treatise, Harvard: Harvard University Press, 1994.

D. BAXTER, Hume's Difficulty (Time and Identity in the Treatise), London and New York: Routledge, 2008.

L. FAlKenstein, "Space and Time“, in S. Traiger (ed.), The Blackwell Guide to Hume's Treatise, London: Blackwell, 2005, s. 59-76.

M. FrASCA-SPADA, Space and the Self in Hume's Treatise, Cambridge: Cambridge University Press, 2002.

D. Hume, A Treatise of Human Nature: Two volume set (The Clanderon Edition of the Works of David Hume), Volume 1, Oxford: Oxford University Press, 2007.

D. HumE, An Enquiry Concerning Human Understanding (The Clanderon Edition of the Works of David Hume), Oxford: Oxford University Press, 2000.

D. HuME, Zkoumání lidského rozumu, Praha: Svoboda, 1972 (překl. V. Gaja).

D. HuME, Zkoumání o lidském rozumu, Praha: Svoboda, 1996 (překl. J. Moural).

O.A. JoHnSON, „Time and the Idea of Time“, in Hume Studies XV (1), 1989.

T. KunCA, "Čas, jak se ukazuje lidské mysli (v Traktátu Davida Huma)“, in Časovost a smrtelnost (Studie k časové konstituci lidské existence), Praha: TOGGA, 2009 (v tisku).

T. KunCA, „Výzkumný program „zeměpisu mysli“ Davida Huma a otázka filosofické fundace kognitivních věd v monografii Karla Pstružiny Svět poznávání“, in Acta Oeconomica Pragensia, Praha: VŠE, 2000.

E.C. Mossner, The Life of David Hume, Oxford: Clanderon Press, 2001.

D. F. NorTON (ed.), The Cambridge Companion to Hume, Cambridge: Cambridge University Press, 1993.

D.F. NORTON, „Historical Account of A Treatise of Human Nature from its Beginnings to the Time of Hume's Death", in D. HumE, A Treatise of Human 
Nature: Two volume set (Clanderon Edition of the Works of David Hume), Volume 2, Oxford: Oxford University Press, 2007, s. 433-588.

D.F. NORTON a M.J. NORTON (eds.), „Editors`Annotations“, in D. HuME, A Treatise of Human Nature: Two volume set (Clanderon Edition of the Works of David Hume), Volume 2, Oxford: Oxford University Press, 2007, s. 685-979.

R. READ a K.A. Richman (eds.), The New Hume Debate, London and New York: Routledge, 2006.

N.K. SMITH, The Philosophy of David Hume: With a New Introduction by Don Garrett, New York: Palgrave Macmillan, 2005 (1941).

S. Traiger (ed.), The Blackwell Guide to Hume's Treatise, London: Blackwell, 2005. 